\title{
On the experience of health professionals' information competence formation in the framework of continuing professional education
}

\author{
Sobre uma experiência em criar competências de informação de \\ profissionais de saúde no quadro de formação profissional contínua
}

\section{Sobre la experiencia de la formación de la competencia informacional de los profesionales sanitarios en el marco de la formación profesional continua}

\author{
Elena Yu. Nikitina ${ }^{1}$ (D), Larisa Yu. Ovsyanitskaya² ${ }^{\text {iD }}$, Natalia V. Butenko ${ }^{1}$ iD, \\ Marina V. Zhukova1 ${ }^{\text {iD }}$, Lidiya P. Rulevskaya ${ }^{3}$ iD
}

\begin{abstract}
${ }^{1}$ South-Ural State Humanitarian Pedagogical University, Chelyabinsk, Russian Federation.
${ }^{2}$ Financial University under the Government of the Russian Federation, Chelyabinsk branch, Chelyabinsk, Russian Federation

${ }^{3}$ Lyceum No. 142, Chelyabinsk, Russian Federation.
\end{abstract}

Corresponding Author:

Elena Yu. Nikitina

Email: elenaurievna@bk.ru

How to cite: Nikitina, E. Y., Ovsyanitskaya, L. Y., Butenko, N. V., Zhukova, M. V., \& Rulevskaya, L. P. (2021). On the experience of health professionals' information competence formation in the framework of continuing professional education. Revista Tempos e Espaços em Educação, 14(33), e16323. http://dx.doi.org/10.20952/revtee.v14i33.16323

\begin{abstract}
Immediacy of such a problem as health professionals' information competence formation is due to the necessity of continuing improvement of pedagogical approaches, methods and technologies of educating medical staff how to use information technologies in their professional activity to provide for their correspondence to the stable and outrunning level of society development in the process of education and healthcare digital transformation. The article aims at the formation of methodological approaches to the pedagogical process studying the use of information technologies in the framework of post-graduate continuing education of health professionals taking into account their professional requirements and work specifics. The leading method of the problem study is the method of involved observation that enabled to make authentic comparison and analyze inquiries of 349 professionals attending the courses of continuing education. The article shows that the applied pedagogical approaches and methods have to correspond to the modern level of information technologies and digital education development, characterized by qualitative changes in the technologies that process and transfer data and widely use the intellectual decision
\end{abstract}


making systems. It states the results obtained in the practical implementation of the offered theoretical and methodological approaches to the process of health professionals' information competence formation. This results in the developed complex of methodological approaches to teaching information technologies at the general scientific, specific scientific and method and technological levels enabling the formation of health professionals' information competence. The article can be useful for students and teachers of pedagogical universities, teachers of medical universities and institutions involved in health professionals' continuing education.

Keywords: Health professionals. Information competence. Continuing professional education. Methodological approaches.

\section{RESUMO}

Um problema em criar competências de informação de profissionais de saúde é importante visto que as abordagens pedagógicas, métodos e tecnologias para a formação de médicos para usar tecnologias de informação em atividades profissionais devem ser constantemente aperfeiçoados para o seu cumprimento do nível sustentável e avançado de desenvolvimento da sociedade durante transformações digitais em educação e serviço de saúde. O artigo destina-se à formação de abordagens metodológicas para o processo pedagógico de aprender utilização das tecnologias de informação no quadro de formação profissional adicional de pós-graduação de profissionais de saúde, tendo em conta suas necessidades profissionais e características específicas do trabalho. 0 método principal para estudar este problema é um método de observação participante, que proporcionou uma avaliação e análise autênticas de inquéritos a 349 profissionais de saúde matriculados em cursos de formação profissional adicional. $O$ artigo demonstra que as abordagens e métodos pedagógicos usados devem corresponder ao nível atual de desenvolvimento das tecnologias de informação e educação digital, que se caracterizam por alterações qualitativas em tecnologias de processamento e transmissão de dados e por utilização generalizada de sistemas inteligentes de tomada de decisão. $O$ artigo inclui os resultados de implementação prática das abordagens teóricas e metodológicas recomendadas para formação de competências de informação em profissionais de saúde. O resultado é um conjunto desenvolvido de abordagens metodológicas para ensinar tecnologias de informação a nível científico, científico-específico e metodológico-tecnológico, propício para criar competências de informação em profissionais de saúde. Os materiais do artigo podem ser úteis a estudantes e professores de universidades pedagógicas, professores e organizadores do processo educativo de universidades médicas e instituições de ensino que se dedicam à educação profissional contínua de profissionais de saúde.

Palavras-chave: Profissionais de saúde. Competência de informação. Formação profissional contínua. Abordagens metodológicas.

\section{RESUMEN}

La relevancia del problema de la formación de la competencia informacional de los profesionales de la salud se debe a la necesidad de la mejora continua de los enfoques pedagógicos, métodos y tecnologías para la formación de los trabajadores médicos en cuanto al uso de las tecnologías de la información en las actividades profesionales para su congruencia con el nivel sostenible y avanzado de desarrollo de la sociedad en el proceso de transformaciones digitales de la educación y la salud. El artículo tiene como objetivo formar los enfoques metodológicos al proceso pedagógico del estudio de la aplicación de las tecnologías de la información en el marco de la formación profesional complementaria de posgrado de los profesionales de la salud, teniendo en cuenta sus necesidades profesionales y las especificidades del trabajo. El método principal para el estudio de esta problemática es el método de observación participativa, que permitió realizar una auténtica valoración y el análisis de encuestas de 349 profesionales de la salud que se han matriculado en cursos de formación profesional complementaria. El artículo muestra que los enfoques y métodos 
pedagógicos aplicados deben corresponder con el nivel actual de desarrollo de las tecnologías de la información y la educación digital, que se caracterizan por cambios cualitativos en las tecnologías de procesamiento y transmisión de datos y el uso generalizado de sistemas inteligentes de toma de decisiones. El artículo presenta los resultados de la implementación práctica de los enfoques teórico y metodológico en cuanto al proceso de formación de la competencia informacional de los profesionales de la salud. El resultado es el desarrollo de un conjunto de enfoques metodológicos para la enseñanza de las tecnologías de la información a nivel científico general, el nivel científico y específico y el metodológico y tecnológico, contribuyendo de esta manera a la formación de la competencia informativa de los profesionales sanitarios. Del contenido del artículo pueden beneficiarse los estudiantes y profesores de universidades pedagógicas, así como los profesores y organizadores del proceso educativo de universidades médicas e instituciones educativas involucradas en la formación profesional continua de los profesionales de la salud.

Palabras clave: Profesionales de la salud. Competencia informacional. Educación profesional continua. Enfoques metodológicos.

\section{INTRODUCTION}

Healthcare is currently one of the most significant and highly technological areas of human activity. It is stringent that specialists in any healthcare area (therapeutic, diagnostic, organizational, preventive and scientific) use information technologies in their activity.

Due to pressing social, economic and technological changes that occur at this time, health professionals are expected to constantly increase their level of information competence. The competence is a complex structure that unites learning criteria, psychological makers of the personality, potential capabilities, motivation, system of values, responsibility, and anticipation of action outcomes manifested when using digital technologies to solve practical tasks to provide population with medical aid, preserve and improve its quality of life.

Aggressive dynamics of environmental processes and phenomena, infomedia increased density, constant information update, and use of highly technological diagnostic and therapeutic equipment make continuous education in information technologies acquire particular importance for health professionals.

Scientific solution of any issue requires a distinct methodological regulation which is an important attribute of any conception determining its type, nature, the system of principles and methods of organization and building theoretical and practical activity. That is why developing a set of methodological approaches at the general scientific, specific scientific and methodology and technology levels of studying the way the information competence of health professionals is formed belongs to the pressing issues.

\section{The current situation in the sphere of continuous professional education of health professionals}

According to the Russian Ministry of Public Health Order 'On approval of the procedure and time for enhancing the professional knowledge and skills of healthcare providers and pharmacists using additional professional educational programs in educational and scientific institutions', it is the employer who determines whether professional retraining and pupillage is necessary after graduation of the university. However, they must be carried out at least once every 5 years during the entire labor activity.

The use of modern information technologies is one of the issues considered within the frames of the state additional professional training of doctors. The attendees belong to highly qualified professionals who use modern digital diagnostic and therapeutic equipment and software needed for proper functioning of medical institutions on a daily basis. 


\section{Peculiarities of teaching information technologies in the courses of additional professional education of health professionals}

The educated health professionals represent various medical institutions that differ by a territorial attribute and department participation, size, equipment and specialization. A number of hours when informational support is studied is low. In a modern world, a competent specialist and a director must foresee how the situation can be developed, be aware that specific information must be obtained, know how to get the needed information selecting a proper source, be able to analyze, synthesize, use, transfer data using modern means of telecommunications and build it in its activity, and use it to solve practical and research tasks (Ovsyanitskaya \& Yurasova, 2015a).

That is why it is necessary not only to cover the novelties of health maintenance hardware and software, changes in the legislation related to the informational support of medicine, features of automatized process of personal and confidential information but also to show the vector of medical informatics development.

\section{Status of a problem}

Health professionals are highly qualified people with a good professional and social status. They are capable of studying and are highly motivated to education: they study and participate in meetings, consultations and conferences on a daily basis. That is why they treat the process of education not as a new activity but as a continuing regular professional activity.

The educated health professionals represent various medical institutions from village hospitals to large federal centers. Thus, specific theoretical and methodological approaches to teach courses related to the use of informational technologies in medicine must be developed. The approaches should take into account the specific features related to the organizational, professional and psychological features of all health professionals who attend the courses.

Knowles (1984), Zmeev (2007), Chychuk, V. (2015) and others describe the features of methodological approaches that have to be used when working with adults. Hesse-Biber (2015), Nind \& Lewthwaite (2018), Clark et al. (2017), Knewstubb \& Nicholas (2017), Nilsa et al. (2016) discuss complex methodologies of teaching interdisciplinary disciplines at universities. Blumental \& Glaser (2007), Masic et al. (2011) reviewed the issue of teaching informational technologies to health professionals. Cartelli (2012) presented the results of modern technologies studies in digital literacy and medical competence.

\section{Study hypothesis}

The authors solved the following tasks during the study: 1 ) select experimental and control groups of health professionals; 2 ) teach the experimental groups using the offered theoretical and methodological approaches; teach the control group using traditional methods; 3 ) compare the levels of information competence of health professionals in the experimental and control groups; 4) analyze the experimental results, estimate the effectiveness of health professionals' information competence formation.

\section{METHODOLOGY}

\section{Study objectives}

It is necessary to develop and implement the methodology of teaching the modules related to the usage of information technologies in medicine to form information competence of health professionals that will consider the age, module specificity and high educational level of doctors. 


\section{Theoretical and empirical methods}

The authors used a complex of various complementary methods to check the hypothesis. These included theoretical (analysis of literature, regulatory, legislative, guidance, working documents and materials related to the study object; study and generalization of innovation pedagogical experience, analysis, and synthesis) and empirical methods (participant observation, summative and formative pedagogical assessment, questioning, testing, interview, conversation pieces and methods of mathematical statistics).

The authors used the authentic assessment to estimate how the material was studied. The assessment is used in practice-oriented education and estimates knowledge and practical skills of those who study in a classroom under the conditions that were close to the real life, both daily and professional.

\section{Study base}

The Ural State Medical Academy of Additional Education and therapeutic institutions of Ekaterinburg, Zlatoust, Kurgan, Chelyabinsk, Magnitogorsk, Miass, Orenburg, Orsk, Tyumen formed the study base.

\section{Stages of the study}

The study had three stages.

During the first stage, the authors examined the specific features that have to be considered when teaching informational technologies in medicine and stated pedagogical conditions needed for successful achievement of the purpose.

The investigators developed the suggested theoretical and methodological approaches to health professionals' information competence and implemented them into the real pedagogical practice at the second stage.

The third stage generalized the results of the pedagogical experiment to produce information competence in health professionals using the traditional and suggested method and considering implementation of all substantiated pedagogical conditions.

\section{Assessment criteria}

The authors assessed whether the education was effective based on the results obtained by health professionals when solving case problems that approached the real professional activity to the greatest possible extent. Tests reflecting various aspects of information competence were offered as well. The authors processed the results with the methods of mathematical statistics.

\section{The course and description of the study}

\section{Uniar approach as the general scientific basis of research}

By choosing the methodology that will be the general scientific basis of our study, the authors first and foremost examined the connection between informatics and medicine.

Medicine and informatics are sundered like the poles. They developed independently for thousands and decades of years, respectively. In the middle of the $20^{\text {th }}$ century the sciences came into contact as electronic means of data processing appeared. Joint developments occurred. However, there was no integration of these sciences.

Analysis of interrelation between medicine and informatics within the last decades showed that it is neither integrative (mutual penetration or union of any elements) nor transdisciplinary (joint trial or studying of either one subject, object, environment, or transfer of the study methods 
of one science to study another science in order to obtain the result). When informatics and medicine interact, one science helps the other one to reach a high qualitative level without interfering into the science that develops in parallel. A need in the development of subsequent technologies can initiate their development.

The authors introduced the term 'uniar' (unio (lat.) means union) denoting the principle of development for parallel sciences by joint solution of the occurring needs (Ovsyanitskaya, 2015b). It results in the occurrence of qualitatively new technologies in every interacting science. Considering the uniar interaction between medicine and informatics and taking education as continuing professional activity of health professionals, the authors presumed that the approach to interaction between the teacher and healthcare professional must be uniar as well.

A uniar approach is a methodological approach that enables the interacting subjects of the pedagogical process to solve the occurring tasks. The main notion mentioned in the educational process when using the uniar approach is uniar interaction (communication between a teacher and a student aimed at the joint solving of occurring professional issues).

The basic method of educational process construction based on the uniar approach is the dialogue method. That is how the discussed issues became diversified and pressing. Moyles et al. (2002), Nind et al. (2015) and Powell (2005) discussed how to include the dialogue into the educational process.

Currently the situation changes so fast that to follow the points above, a teacher needs continuous knowledge of various aspects associated with the application of informational technologies in medicine. Health professionals attending the courses of post-graduation and continuous education for doctors form the only available source of reliable, pressing, diversified and adequate data.

Uniar interaction is a management process with an obligatory feedback. A teacher's task is to develop the educational process so that the data obtained during discussions or when doing home tasks associated with healthcare issues for their companies and institutions, public solution of cases could become the correcting module that makes a lesson pressing, useful and highly professional.

This approach is based on the elements of mutually profitable and interesting dialogue. It creates a climate of partnership in class enabling health professionals to improve their qualification in the sphere of information technologies and letting teachers be aware of the current needs of medicine in information technologies as well as modify and adapt the lesson for other groups.

\section{Systemic and synergetic approach as the specific scientific basis of research}

The specific and scientific methodology of our study includes the systemic and synergetic approach. The approach is a set of principles that determine the purpose and strategy of complex issue solution. This method takes an object (that has a problem) as a system, decomposes a complex problem into elements, and retains the elements as a whole. First, the synergetics appeared in studies of natural science. Then as the principles that manage the self-organization processes don't depend on the nature of the systems, the synergetics turned into a multidisciplinary approach within the frameworks of modern world view philosophical concepts. The system can never be taken separately from the environment which is also a complex system, in its turn. In synergetics, an emphasis is made on the conformity of interaction of elements when a single unity is formed (Hall \& Howard, 2008).

According to the studies, the pedagogical system of continuing education of doctors is a functionally managed dynamic direct-feedback structure consisting of a set of subjects of the pedagogical process (teacher, health professionals and employees engaged in the organizational and methodological activity), contents, methods, forms, material resources and means of the pedagogical process. It was created to approve regular education of health professionals by statute. 
To properly apply the methodology of synergetics when building health professionals information competence, the system of continuing education of doctors must correspond to the required criteria and represent an open, self-organizing and non-linear system.

An open system is a system that exchanges data, substance or energy with the environment. Continuing education of health professionals means that there is a constant exchange of data and knowledge between teachers, practitioners at the medical institutions where some classes are held, and attendees. When a conversation is managed based on the principles of synergetics, the obtained inconsistent data (facts, ideas, proposals bon during a conversation, personal and professional experience) can be turned into qualitative knowledge that can be implemented by attendees after the course.

Self-organization is a process or processes inside the system that enable its optimal functioning, self-restoration and self-change. It is typical of andragogical systems. Self-organization arises when there is an interaction between an accident and necessity. It is associated with the transition from instability to stability. Initially all attendees have different levels of theoretical and practical training in the sphere of informational technologies and a recognized necessity in generating a high level of information competence. Implementation of attendees' individual educational paths, change in the rate of group education if needed and use of individual means and methods.

Non-linear values are as follows: availability of alternative ways of development and possibility of their selection; ability to influence the rate of process development; irreversibility of the process after selection of a variant. The educational process is mostly optimized at the stage of its planning and design. However, a more freely format and lack of strict reference to training subject matter (as compared to secondary and higher education) allows a teacher to deviate from the selected plan and get an optimal decision considering the purpose set and pedagogical possibilities available. That is why professional training of a teacher (specializing in adragogy), intuition and additional lectures, multilevel study guides and control activities promote a reasonable change in the method, form and content of the lesson depending on the current need and initial training of attendees.

Optimization of the educational process means to study the required theoretical basis, solve pressing issues associated with the implementation of information technologies and getting practical skills needed for this group of attendees within a restricted interval.

Accidental replies and queries of attendees that arise during a conversation often seem important and interesting to everyone.

Adequate management of the educational process will lead to new knowledge and skills that could not be anticipated before.

Thus, use of the systemic and synergetic approach as a general scientific basis of the study enabled us to study the process of formation of health professionals' information competence by decomposing the systems, analyzing possible subsystems, their interrelation considering peculiar features attributable to the educational process of adult highly qualified people. Meanwhile, the basic attention was given to subsystems and their interrelation as parts of the whole i.e. the process of generating the information competence.

\section{Cybernetic approach as the methodological and technological study basis of research}

The cybernetic approach in our study forms its methodological and technological basis. As the system theory was cybernetic-based, the described methodological principles mostly reflect the cybernetic requirements. With the development of digital education, this approach acquires high prevalence (Williamson, 1915)

In cybernetic terms, the described system of advanced training as a whole is called 'a big system' i.e. it can be represented by a set of subsystems with constantly decreasing complexity. 
Cybernetic pedagogics treats the educational process from the point of view of management theory and on the basis of the systemic approach. Indeed, the educational process can be taken as a management process that has the managing (teacher) and managed (attendee) parties.

Considering the specific features of health professionals' continuing education environment, educational optimization is an algorithm of the teacher's actions related to the substantiation, implementation and control of qualitative educational decisions under specific conditions, and in the least necessary losses of time and efforts by attendees and teachers. A conscious need in motivated, responsible professionals with the system of values and capable of predicting their results when using digital equipment and technologies to provide for medical care of population can be considered as the basic control response.

Considering the formulated principles of cybernetics as related to the didactic systems (Mayer, 2013) we adapted the cybernetic sequence of management to the formation of information competence of health professionals.

First and foremost, the authors analyze the pedagogical system based on the systemic and synergetic approach. The target, component, comprehensive, deductive, subjective, and effective subsystems are selected and analyzed; their relations are assessed. Then the authors examine the management object (health professionals' activity), i.e. its basic knowledge, skills, experience, personality traits of the attendees associated with the age and digital equipment operation experience using the specialized initial testing or conversation. This is how gaps and achievements in the analyzed values were found.

Business Intelligence in MS Excel is an instrument analyzing the data of pedagogical monitoring. The use of data intellectual analysis provides for a multi-level processing of pedagogical monitoring data, reveals factors influencing the result and corrects the subsequent work of the educational institution i.e. produces pedagogical management.

We develop and implement the optimal management strategy (program):

Formalized visualized data promote scientific planning of not an abstract but a specific lesson for certain people anticipating possible difficulties in mastering the educational material or no need to study a topic in detail. The optimal strategy (program) of management is developed and implemented: a fixed program if a lesson is given according to a pre-defined plan with insignificant regulation; a flexible program which is adjusted to the changing conditions preserving the system targeting and expedience.

Joint use of cybernetic and systemic and synergetic approaches enable to achieve as follows: the cybernetic approach studies the interrelation between a subject and an object of management following the direct-feedback channels and enables to define the ways of influencing the objects. Meanwhile, synergetics examines the reasons for the system properties.

\section{RESULTS}

\section{Pedagogical conditions that promote the optimal achievement of the set objective}

When conducting theoretical studies and pedagogical research, the authors set the pedagogical conditions that enabled to practically implement the theoretical approaches suggested above for every level. The list of pedagogical conditions that promote successful achievement of the set purpose, i.e. health professionals' information competence formation to the greatest extent, is as follows:

- to use the means and methods of education adapted to the andragogical environment;

- to organize lessons based on the principles of synergetics and uniar interrelation between a teacher and health professionals where their professional problems and requirements are discussed; 
- to assign some material for self-learning;

- to look through some regulations covering how to treat the data;

- to use active methods of education (case-technologies, business games, context education);

- to use intellectual methods of data mining to reveal hidden regularities and generate recommendations on the introduction of dynamic corrections into the self-guided work, development of individual educational paths for health professionals based on the obtained recommendations.

\section{The course and results of the experiment}

The authors performed an experimental work that enabled mathematical substantiation of the revealed tendencies and checking the effectiveness of the integrity of the offered pedagogical methods to generate the information competence of health professionals within the framework of continuing professional education to confirm the effectiveness of the developed approaches.

The stated objective determined the type of the basic tasks solved during the exploratory work:

- $\quad$ to determine the level of health professionals' information competence before training and if the traditional method is used;

- $\quad$ to develop the programs that diagnose the formation of health professionals' information competence within the framework of continuous professional education considering the specifics of medicine;

- $\quad$ to select and argue representativeness of the sample and statistical criteria that evaluate the working results;

- $\quad$ to evaluate the significance and tendency of changes during training;

- $\quad$ to find the most significant factors influencing the process of health professionals' information competence formation.

Health professionals conditionally divided into two groups (control group (CG-172 people)) and experimental group (EG-177 people) participated in the experimental work.

At the first stage, a test was used to find the initial level of health professionals' information competence. Comparison of its levels showed that health professionals from the both groups had a similar level of information competence development.

The number of health professionals with a low level of information competence was $35.47 \%$ in the CG and $25.99 \%$ in the EG; mid-level $-64.53 \%$ in the CG and $74.01 \%$ in the EG; and there was no high level.

The obtained results showed that competence of health professionals in informational technologies was problematic. The conducted statistical estimation confirmed the significance of the obtained results and homogeneity of the initial experimental conditions.

The authors obtained the following results after health professionals completed the courses. The CG used traditional methods whereas the EG implemented the approaches described above. After the training was completed, a number of health professionals with the mid-level of informational competency was $90.12 \%$ in the CG and $7.91 \%$ in the EG; high level $-9.88 \%$ in the CG and $92.09 \%$ in the EG; and there was no low level. Fig. 1 displays the results before and after the experiment. 
Figure 1. The ratio between the levels of information competence in the CG and EG before and after the experiment

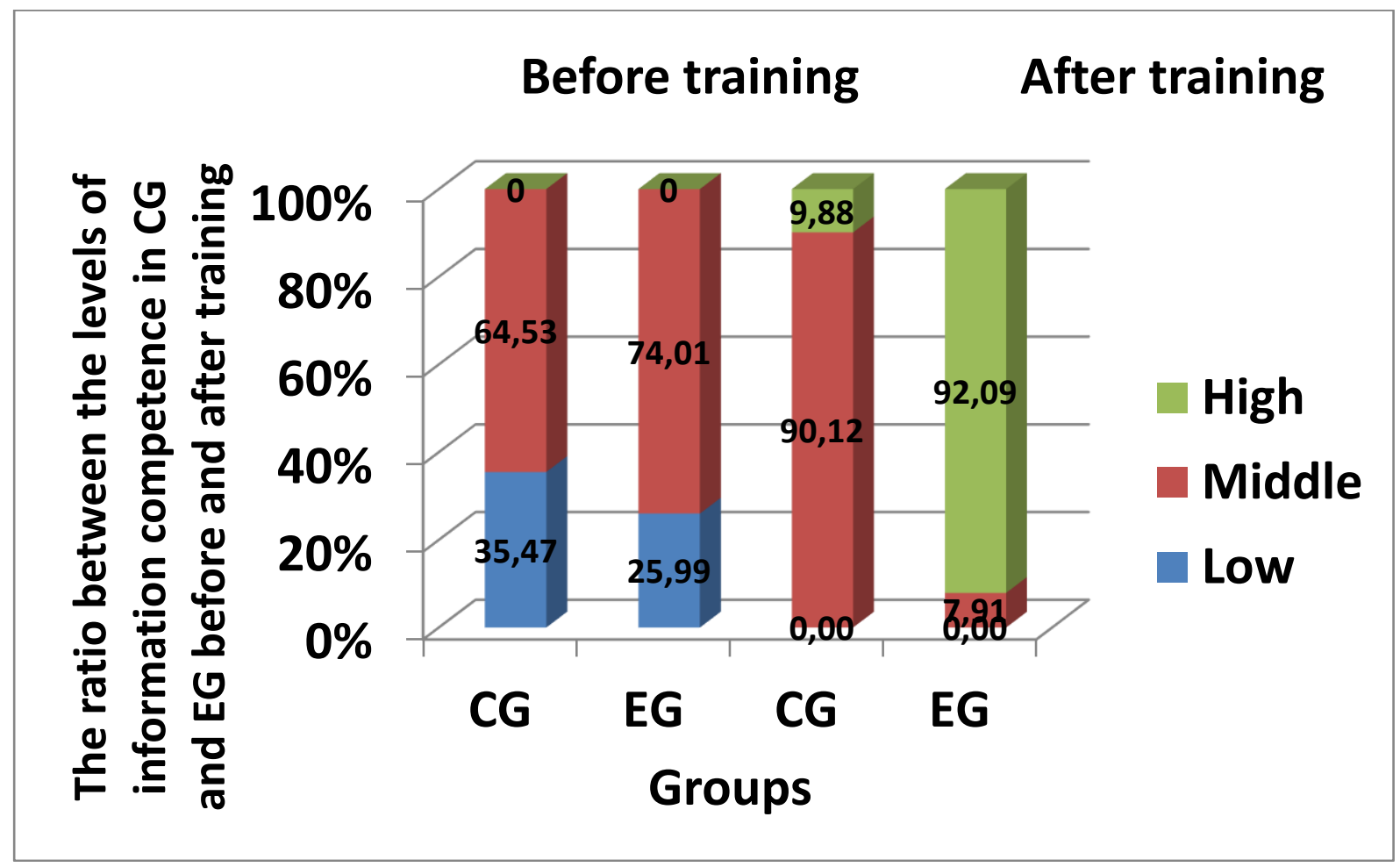

The results of tests, questionnaire, observation and conclusion based on the results of discussion by health professionals of the tasks that display a real situation associated with the use of information technologies to provide medical assistance to people were the primary entry data sources.

The experimental results show that implementation of the described theoretical approaches into the pedagogical practice was effective and confirm the rationale.

\section{DISCUSSIONS}

Currently occurring social, economic and technological changes were the main conditions of formation of health professionals' information competence. High level of education and specific activity of doctors require specific methodological approaches to the building of the pedagogical process.

The experiment compared the level of formation between the two groups of health professionals. The study showed a significant growth of the controlled parameters in the experimental group as compared to the control group educated using the traditional method.

\section{CONCLUSION}

The integration of the uniar approach as the general scientific basis, systemic and synergetic approach as the specific and scientific basis and cybernetic approach as the methodical and technological basis for the method of health professionals' information competence formation suggested in the article enables to form the process of continuing education for health professionals in the sphere of informational technologies considering modern pedagogical requirements and trends of society development.

The testing results described in the article will be useful for teachers of medical universities and institutions involved in continuing education of health professionals. 
Authors' Contributions: Nikitina, E.Y.: acquisition of data, analysis and interpretation of data, drafting the article; Ovsyanitskaya, L.Y.: conception and design, analysis and interpretation of data, critical review of important intellectual content; Butenko, N.V.: conception and design, analysis and interpretation of data, critical review of important intellectual content; Zhukova M.V.: drafting the article, critical review of important intellectual content; Rulevskaya L.P.: acquisition of data, critical review of important intellectual content. All authors have read and approved the final version of the manuscript.

Ethics Approval: Not applicable.

Acknowledgments: Not applicable.

\section{REFERENCES}

Blumental, D., \& Glaser J. (2007). Information Technology Comes to Medicine. The New England Journal of Medicine, 356, 2527-2534.

Cartelli, A. (2012). Current Trends and Future Practices for Digital Literacy and Competence. Hershey, PA: Information Science Reference.

Chychuk, V. (2015). Approaches to Training Teachers of Adults in the UK. Comparative Professional Pedagogy, 5(1), 7479.

Clark, J., Laing, K. , Leat, D., Lofthouse, R., Thomas, U., Tiplady, L., \& Woolner., P. (2017). Transformation in Interdisciplinary Research Methodology: The Importance of Shared Experiences in Landscapes of Practice. International Journal of Research and Method in Education, 40 (3), 243-256.

Hall, Bronwyn, \& Howard, Kirsten (2008). A Synergistic Approach Conducting Mixed Methods Research With Typological and Systemic Design Considerations. Journal of Mixed Methods Research.

Herbst-Damm, K. L., \& Kulik, J. A. (2005). Volunteer support, marital status, and the survival times of terminally ill patients. Health Psychology, 24, 225-229.

Hesse-Biber, S. (2015). The problems and prospects in the teaching of mixed methods research. International Journal of Social Research Methodology.

Knewstubb, B., \& H. Nicholas (2017). From Model to Methodology: Developing an Interdisciplinary Methodology for Exploring the Learning-Teaching Nexus. International Journal of Research \& Method in Education 40(3), $270-287$.

Knowles, M. (1984). Andragogy in Action. San Francisco: Jossey-Bass.

Masic, I., Pandza, H., Toromanovic, S., Masic F., Sivic, S., Zunic, L., \& Masic, Z. (2011). Information Technologies (ITs) in Medical Education. Acta Inform Med, 19(3), 161-167.

Mayer, R.V. (2013). Cybernetic Pedagogy: Simulation modelling of the learning process. Glazov: GGPI.

Moyles, J., Adams, S., \& Musgrove, A. (2002). Using Reflective Dialogues as a Tool for Engaging with Challenges of Defining Effective Pedagogy. Early Child Development and Care, 172(5), 463-478.

Nilsa, A., Bosque-Pérez, P., Zion, Klos Jo, Force, Ellen, Lisette, P., Waits, Kate, Cleary, Paul, Rhoades, Sara M., Galbraith, Amanda L., Bentley, Brymer Michael, O’Rourke, Sanford D., Eigenbrode, Bryan, Finegan, J.D., Wulfhors Nicole, Sibelet, Joseph, \& Holbrook, D. (2016). A Pedagogical Model for Team-Based, Problem-Focused Interdisciplinary Doctoral Education. BioScience, 66(6), 477-488.

Nind, M., Kilburn, D., \& Wiles., R. (2015). Using Video and Dialogue to Generate Pedagogic Knowledge: Teachers, Learners and Researchers Reflecting Together on the Pedagogy of Social Research Methods. International Journal of Social Research Methodology, 18(5), 561-576.

Nind, Melanie, \& Lewthwaite, Sarah (2018). Methods that teach: developing pedagogic research methods, developing pedagogy. International Journal of Research \& Method in Education, 0(0).

Ovsyanitskaya, L. Yu. (2015a). The andragogical approach application as a general scientific basis for the health professionals" information competence formation. Bulletin of the Tomsk State University, 390, 194-201.

Ovsyanitskaya, L.Y. (2015b). The uniar approach to computer science and information technologies teaching for health professionals. Fundamental research, 4(2), 448-452. 
Ovsyanitskaya, L.Y., \& Yurasova, E.V. (2015a). Information technologies, mechatronics and robotics as a basis of an interdisciplinary approach to engineering and medical education. Bulletin of SUSU, Education series: Pedagogical sciences, 7(4), 101-106.

Ovsyanitskaya, L.Y., \& Yurasova, E.V. (2015b) Mechatronics and robotics as an innovative element in the development of the engineering and medicine education. Bulletin of SUSU, Series of Computer technologies, control, radio electronics, 15(3), 115-123.

Powell, E. (2005). Conceptualising and Facilitating Active Learning: Teachers' Video-Stimulated Reflective Dialogues. Reflective Practice, 6, 407-418.

Williamson, Ben (1915). Digital education governance: data visualization, predictive analytics, and 'real-time' policy instruments.

Zmeev, S.I. (2007). Andragogy: basic theory, history and technology of adult education. Moscow: PER SE.

Received: 31 April 2021 | Accepted: 2 August 2021 | Published: 529 August 2021

This is an Open Access article distributed under the terms of the Creative Commons Attribution License, which permits unrestricted use, distribution, and reproduction in any medium, provided the original work is properly cited. 